\title{
МЕЖДУНАРОДНЫЙ СТУДЕНЧЕСКИЙ ЮРИДИЧЕСКИЙ ФОРУМ «ВЛИЯНИЕ РЕВОЛЮЦИОННЫХ СОБЫТИЙ 1917 ГОДА НА СТАНОВЛЕНИЕ И РАЗВИТИЕ ГОСУДАРСТВА И ПРАВА»
}

\author{
T. А. Сошникова
}

Московский гуманитарный университет

Аннотация: В статье представлен обзор работы Международного студенческого юридического форума «Влияние революционных событий 1917 года на становление и развитие государства и права», который проходил в Московском гуманитарном университете 26-27 октября 2017 г.

Ключевые слова: Московский гуманитарный университет; студенческая наука; юриспруденция; революция 1917 года

\section{INTERNATIONAL STUDENT FORUM “INFLUENCE OF THE 1917 REVOLUTIONARY EVENTS ON THE FORMATION AND DEVELOPMENT OF STATE AND LAW"}

\author{
T. A. Soshnikova \\ Moscow University for the Humanities
}

\begin{abstract}
The paper presents a review of the work of the International Student Law Forum "Influence of the 1917 Revolutionary Events on the Formation and Development of State and Law", which was held at Moscow University for the Humanities on 26-27 October 2017.

Keywords: Moscow University for the Humanities; student science; jurisprudence; 1917 Revolution
\end{abstract}

Принимая о внимание Распоряжение Президента РФ от 19.12.2016 № 412-рп «О подготовке и проведении мероприятий, посвященных 100летию революции 1917 года в России», а также учитывая значимость революционных событий февраля и октября 1917 года, которые оказали колоссальное влияние на становление и развитие государства и права не только России, но и в мировом масштабе, юридический факультет Московского гуманитарного университета принял решение о проведении Международного студенческого юридического форума по теме «Влияние революционных событий 1917 года на становление и развитие государства и права». Форум проходил 26 и 27 октября 2017 года. Соучредителями мероприятия выступили Московский гуманитарный университет, Международный союз юристов, Союз юристов Москвы, региональное отделение 


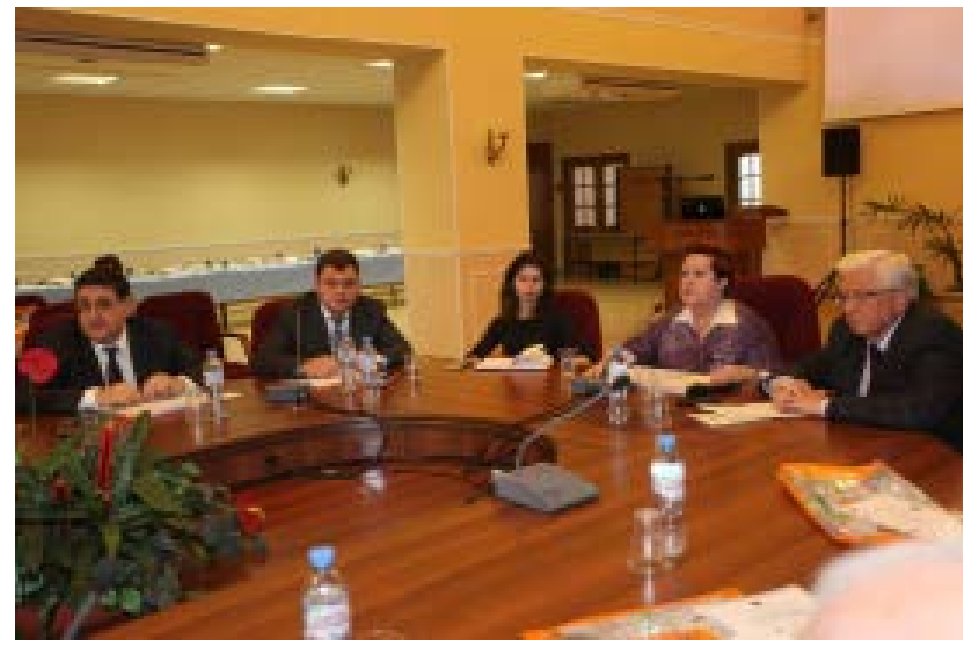

Ассоциации юристов России и Ассоциация юридических вузов. Представители всех перечисленных организаций присутствовали на конференции и им было предоставлено слово для выступления.

Информационную поддержку Форума на протяжении многих лет осуществляет компания «Консультант Плюс», за что организаторы форума ей благодарны. Эта компания в полной мере может быть отнесена к социально ориентированным организациям.

В рамках форума проведен целый ряд мероприятий, в том числе научная конференция, в которой приняли участие ведущие ученые нашей страны и представители зарубежных государств, среди которых историки, юристы, руководители коммерческих компаний и общественных организаций. А параллельно с ней были проведены деловые игры, круглые столы и диспуты.

С приветственным словом от имени руководства МосГу выступил проректор по воспитательной работе и дополнительному образованию Е.А. Белый, который поздравил всех участников с началом работы форума и подчеркнул значимость революционных событий 1917 года и важность их научного осмысления.

От имени Международного союза юри-

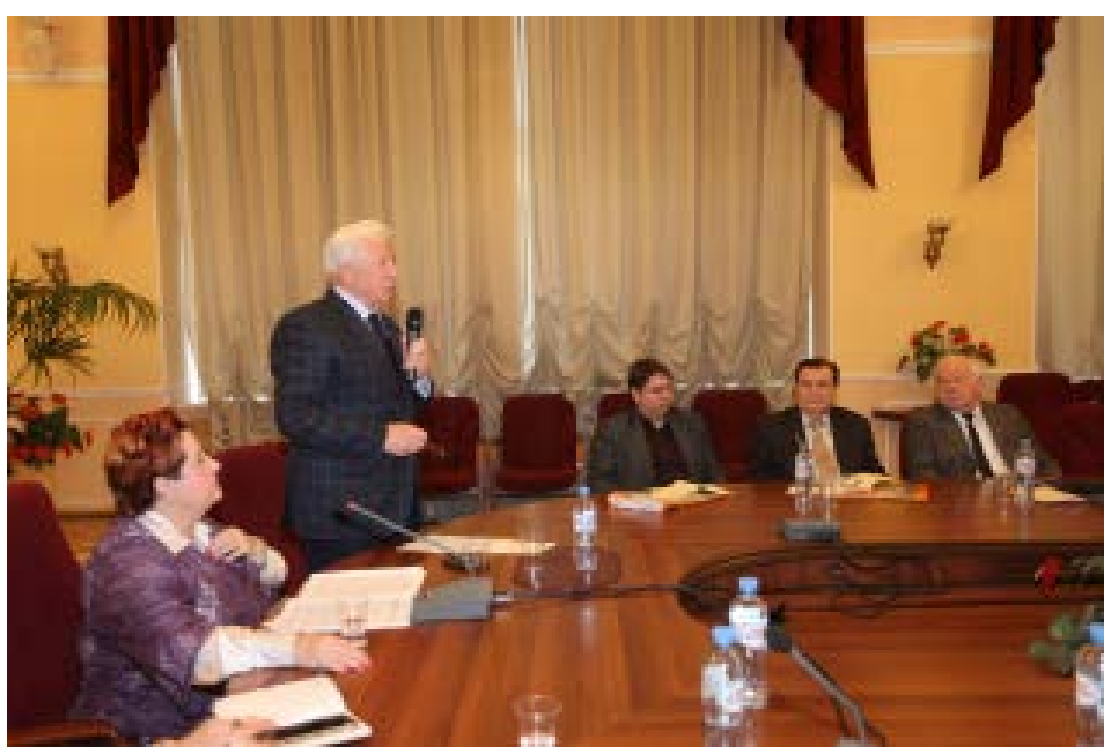
стов выступил Первый заместитель Председателя, доктор юридических наук А. С. Тагиев, который не просто поприветствовал собравшихся, а подготовил серьезный аналитический доклад о Великой Октябрьской социалистической революции и ее влиянии на дальнейший ход истории развития российского государства. Он подчеркнул, что результаты революции с современных позиций оцениваются далеко неоднозначно, од- 
нако отрицать огромное влияние Февральской и Октябрьской революций на становление и развитие современных государств невозможно. Нужно уважительно относиться к своей истории, отметил выступающий.

Первый заместитель Председателя Союза юристов Москвы, арбитражный управляющий М. В. Вильховский не только поздравил участников форума с таким важным научным событием, но и прочитал прекрасное стихотворение Максимилиана Во-

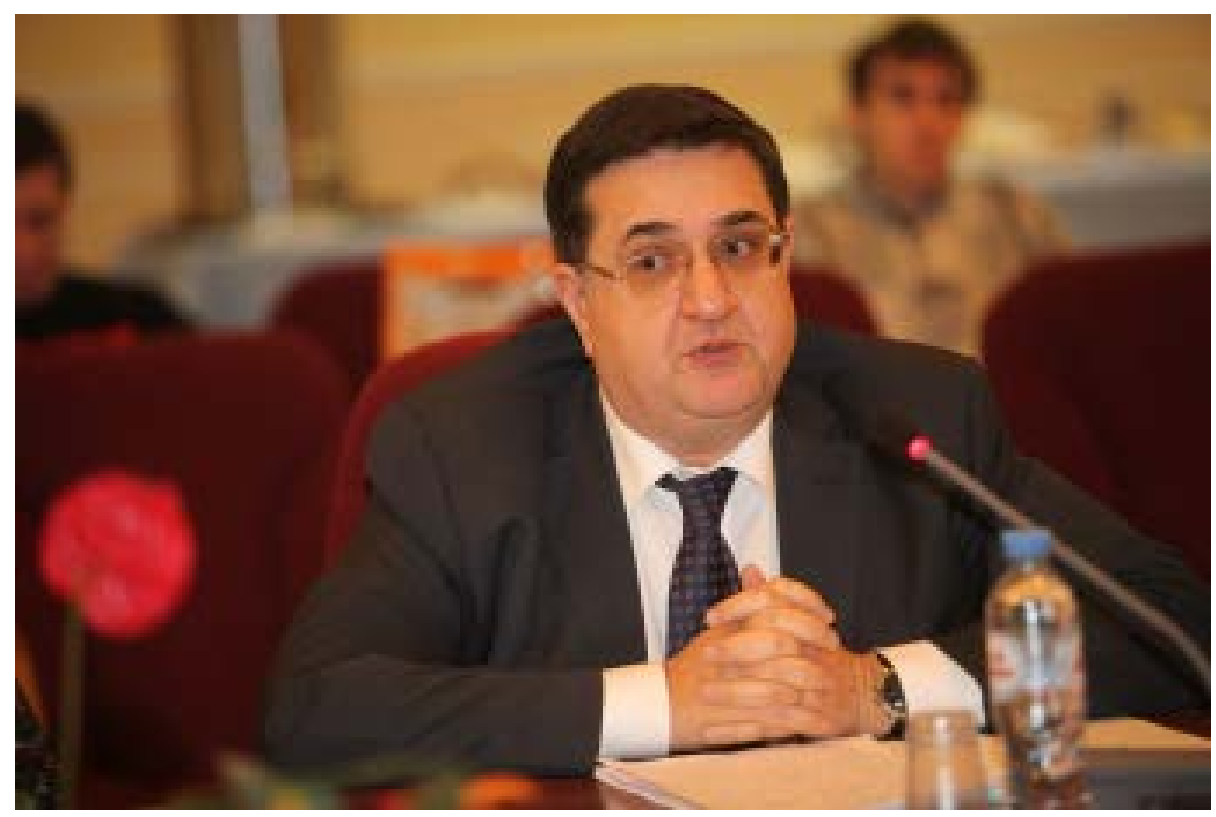
лошина, которое как нельзя лучше походило для темы проводимого юридического Форума.

От имени Регионального отделения Ассоциации юристов России на конференции выступила заместитель Руководителя Управления регионального развития Аппарата Ассоциации юристов России Е. С. Скорнякова. Она поздравила участников форума с открытием важного научного мероприятия и вручила декану юридического факультета Т. А. Сошниковой приветственный адрес, подписанный заместителем Председателя Правления Ассоциации юристов России Д. И. Паньшиным.

Как всегда, с блестящим аналитическим докладом на конференции выступил доктор юридических наук, профессор, Заслуженный юрист РФ, Заслуженный деятель науки РФ, главный научный сотрудник Института государства и права РАН В. Е. Чиркин. Тема его выступления была «Столетняя модификация сущности, содержания и формы российского государства: конституционные аспекты». Он отметил, что социализм, о котором мечтали лучшие умы человечества, в России в результате революции так и не наступил. До 90-х годов прошлого века в России и СССР был социализм тоталитарного характера. Революция 1990-х годов демократическая, однако, при взятии «Белого дома» людей погибло больше, чем при взятии Зимнего дворца.

А. А. Королев, доктор исторических наук, профессор Московского гуманитарного университета подготовил научное сообщение на тему «1917 год в зеркале перемен». Он подчеркнул, что в результате революционных событий 1917 года марксизм в России победил вопреки Марксу. Октябрь- 
ская революция победила в силу субъективных и объективных причин. Но в настоящее время в России велико расслоение людей и не исключены причины для новых революций.

Т. М. Пряхина, доктор юридических наук, профессор кафедры государственно-правовых дисциплин Юридического института Московского городского педагогического университета выступила с научным сообщением на тему «Конституция РСФСР 1918 года и современность». Она назвала Конституцию 1918 года красивой и самой честной, поскольку в ней не было лицемерия, не провозглашались демократические ценности, она закрепляла власть трудящегося народа, которая реализовывалась именно для тех, кто трудится.

К. А. Ахметов, доктор исторических наук, профессор, проректор по учебной и научной работе Евразийского гуманитарного института (г. Астана, Казахстан) выступил с научным сообщением на тему «Октябрьская револиция и культурные преобразования в Казахстане». В своем выступлении он обратил внимание на тот факт, что на становление культурной основы Казахстана огромное влияние оказала российская культура и российское образование.

Б. М. Ашавский, кандидат юридических наук, профессор Дипломатической академии МИД РФ выступил с научным сообщением на тему «Влияние революционных событий 1917

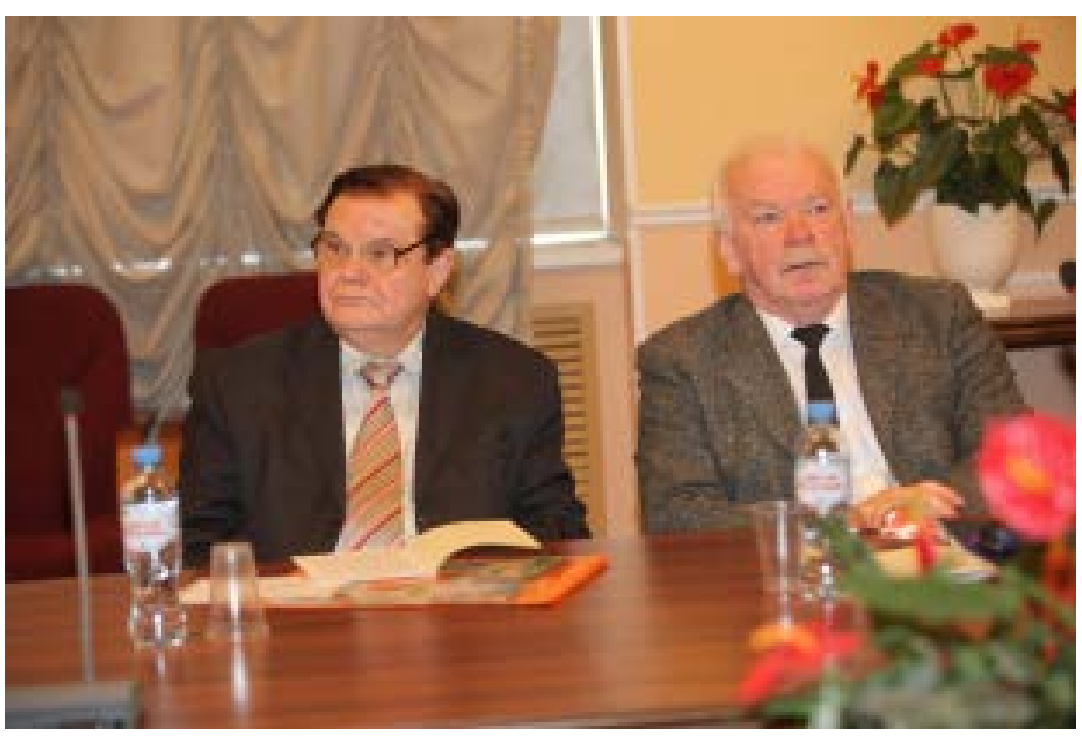
года на становление и развитие международного права». В своем выступлении он провел сравнительный анализ Великой французской буржуазной революции 1789 года и Великой Октябрьской социалистической революции 1917 года и подчеркнул, что именно после Октября 1917 года стало активно развиваться международное право и были приняты важнейшие международные акты Международной организацией труда, которая образовалась в 1919 году и впоследствии ООН.

На конференции выступили студенты многих вузов, в числе которых Университет им. О. Е. Кутафина, РУДН, Академия Генеральной прокуратуры, МГПУ, Университет инклюзивного образования и конечно студенты Московского гуманитарного университета. 


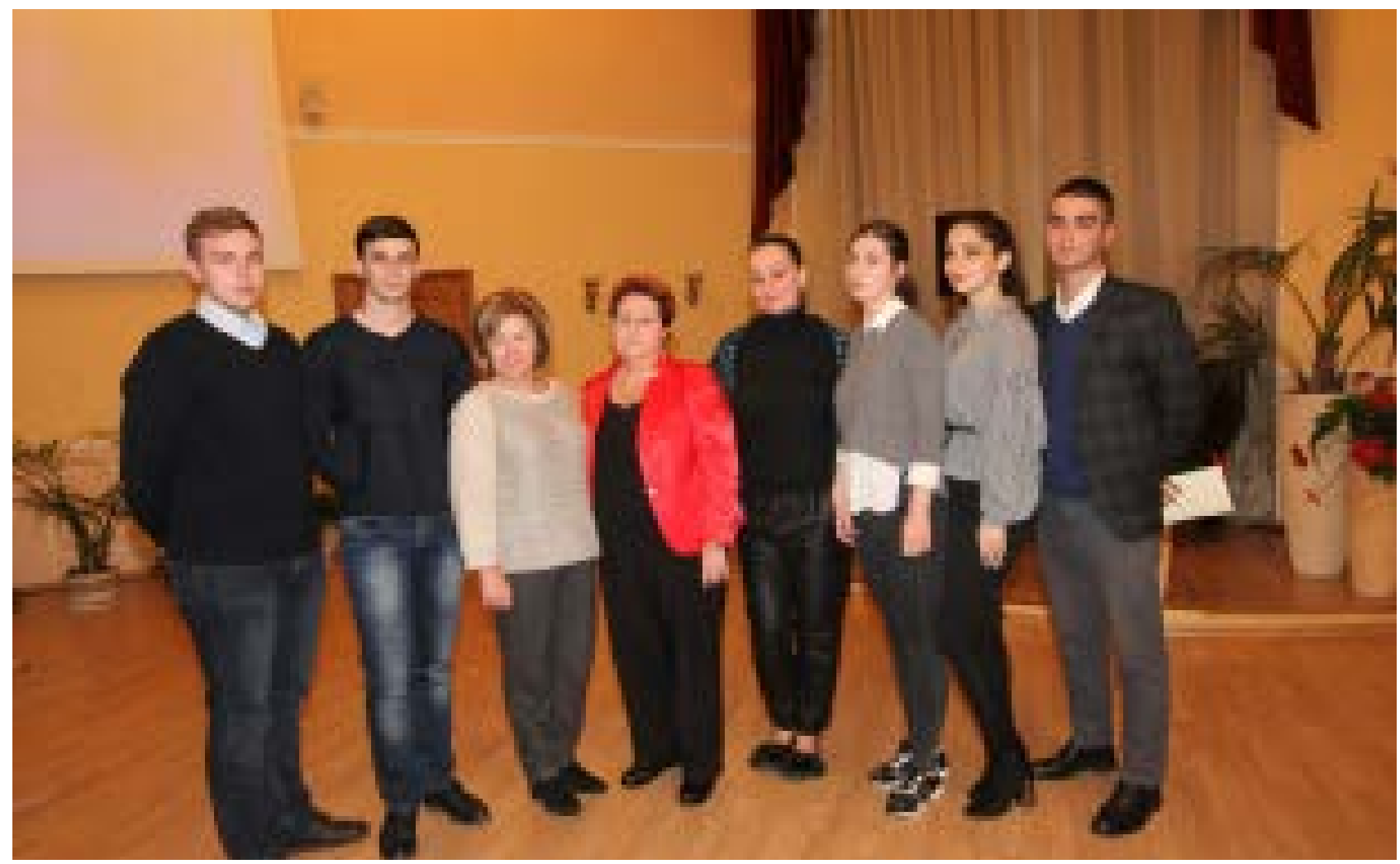

Впервые в конференции и деловых играх приняли участие студенты и магистранты Государственного университета инклюзивного высшего образования «Московский государственный гуманитарно-экономический университет».

Также впервые активное участие в конференции и деловых играх приняли участие студенты и преподаватели Северо-Осетинского государственного университета им. К. Л. Хетагурова (СОГУ).

Впервые на конференции выступил с научным сообщением студент Парижского университета «Пантеон - Ассас Париж-2» Кантер Адриен Пьер Эмиль, который рассказал о Великой французской революции 1789 года и показал ее отличия и сходства с Великой Октябрьской революцией 1917 года. У юридического факультета МосГУ давние деловые контакты с Парижским университетом и ежегодно его студенты обучаются на юридическом факультете, но выступать на конференциях им не удавалось.

В конференции приняли участие представители Евразийского гуманитарного института (Республика Казахстан, г. Астана). Между нашими вузами подписан договор о сотрудничестве, в рамках которого предполагается не только совместное проведение научных мероприятий, конференций, симпозиумов, но и взаимный обмен студентами и преподавателями.

В заключение и студенты, и преподаватели высказали благодарность деканату юридического факультета за очень интересное и важное с точки 
зрения истории, философии, юридической и других гуманитарных наук мероприятие и предложили сделать традиционным проведение подобных юридических форумов.

Дата поступления: 29.10.2017 2.

Сошникова Тамара Аркадьевна - доктор юридических наук, профессор, заведующая кафедрой гражданского процесса и социальных отраслей права юридического факультета Московского гуманитарного университета. Адрес: 111395, Россия, г. Москва, ул. Юности, д. 5. Тел.: +7 (499) 374-72-37. Эл. адрес: soshnikova.ta@mail.ru

Soshnikova Tamara Arkadievna, Doctor of Law, Professor, Head, Department of Civil Procedure and Social Branches of Law, Faculty of Law, Moscow University for the Humanities. Postal address: 5, Yunosti St., Moscow, Russian Federation 111395. Tel: +7 (499) 374-72-37. E-mail: soshnikova.ta@ mail.ru

\section{Для циитирования:}

Сошникова Т. А. Международный студенческий юридический форум «Влияние революционных событий 1917 года на становление и развитие государства и права» [Электронный ресурс] // Научные труды Московского гуманитарного университета. 2017. № 5. URL: http://journals.mosgu. ru/trudy/article/view/571 DOI: 10.17805/trudy.2017.5.9 (дата обращения: дд.мМ.гг.). 